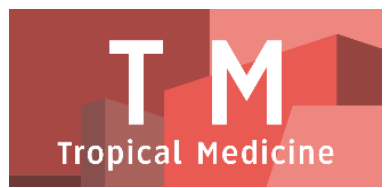

PAPER - OPEN ACCESS

\title{
Pengalaman Ibu Yang Memiliki Anak Autis di Sekolah Luar Biasa (SLB) Binjai: Studi Fenomenologi
}

\author{
Author : : Ayu My Lestari Saragih \\ DOI $\quad: 10.32734 /$ tm.v1i1.43 \\ Paper Page : $87-93$
}

Volume 1 Issue 1 - 2018 TALENTA Conference Series: Tropical Medicine (TM)

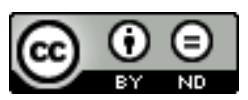

This work is licensed under a Creative Commons Attribution-NoDerivatives 4.0 International License.

Published under licence by TALENTA Publisher, Universitas Sumatera Utara
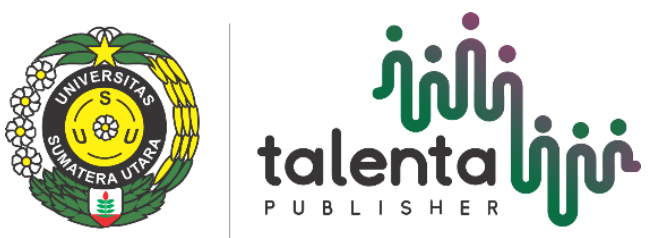


\title{
Pengalaman Ibu Yang Memiliki Anak Autis di Sekolah Luar Biasa (SLB) Binjai: Studi Fenomenologi
}

\author{
Ayu My Lestari Saragih ${ }^{a}$, Dewi Elizadiani Suza ${ }^{a}$ \\ ${ }^{a}$ Departemen Keperawatan Anak, Universitas Sumatera Utara, Medan. 20155, Indonesia \\ ayusaragih09@yahoo.com, dewi1@usu.ac.id, elizadiani@hotmail.com
}

\begin{abstract}
Abstrak
Autis merupakan suatu gangguan perkembangan yang ditandai dengan adanya kekurangan pada aspek komunikasi dan interaksi sosial, kesulitan dalam melakukan komunikasi verbal dan non verbal, tingkah laku terbatas dan berulang. Pengalaman ibu yang memiliki anak yang autis penting untuk diperhatikan karena anak autis memerlukan bantuan dalam berperilaku, memenuhi aktivitas sehari-hari dan membutuhkan arahan dan pengawasan dalam berhubungan dengan orang lain yang menimbulkan ketergantungan yang tinggi pada orangtua khususnya ibu. Penelitian ini menggunakan desain fenomenologi yang bertujuan untuk mengeksplorasi pengalaman ibu yang memiliki anak autis di Sekolah Luar Biasa (SLB) Binjai. Teknik pengambilan sampel yang digunakan adalah purposive sampling dengan jumlah partisipan sebanyak delapan orang. Penelitian dilaksanakan pada bulan Maret sampai dengan Juni 2016. Analisa data menggunakan metode Collaizi. Penelitian ini menemukan 5 tema terkait dengan pengalaman ibu yang memiliki anak autis di Sekolah Luar Biasa (SLB) Binjai, yaitu (1) mengalami masalah psikologis dan fisik, (2) menerima kondisi anak yang mengalami autis, (3) memberi perawatan pada anak, (4) mengalami kendala dalam merawat anak, dan (5) harapan ibu terhadap anak yang mengalami autis. Berdasarkan hasil penelitian ini diharapkan dapat dijadikan sumber acuan dan pertimbangan sekolah untuk meningkatkan wawasan dan keterampilan dalam memberikan dukungan bagi ibu yang memiliki anak autis sehingga orangtua mengerti tentang autis dan perawatannya.
\end{abstract}

Kata Kunci: Ibu; Anak Autis

\section{Pendahuluan}

Gangguan spektrum autism (Autism Spectrum Disorders/ASD) merupakan suatu gangguan perkembangan yang ditandai dengan adanya kekurangan pada aspek komunikasi dan interaksi sosial, kesulitan dalam melakukan komunikasi verbal dan non verbal, tingkah laku terbatas dan berulang (American Psychiatric Association, 2000). Penyebab ASD dianggap sebagai kombinasi genetika dan faktor lingkungan yang belum diketahui [4]. Menurut penelitian Smalley (1997) dalam Emam, Esmat, dan Sadek (2012) gangguan spektrum autism ini terjadi empat kali lebih tinggi pada laki-laki daripada perempuan.

Menurut penelitian Woodgate dan Ateah (2008) tentang pengalaman orang tua yang memiliki anak dengan autisme di propinsi barat Kanada, dari hasil penelitian ini menunjukkan bahwa orang tua yang memiliki anak dengan autisme tidak hanya mempengaruhi peran mereka sebagai orangtua tetapi lebih ke titik mendefinisikan bagaimana mereka hidup di dunia. Orang tua mengalami perasaan berada di dunia mereka sendiri dan berjalan sendiri ke titik yang menjadi esensi dari pengalaman mereka. Penelitian ini juga menemukan bahwa orang tua yang memiliki anak autis merasa terisolasi oleh masyarakat yang kurang pemahaman mengenai autisme. 
Menurut penelitian sebelumnya [5] saat setelah orang tua menerima diagnosis akhir bahwa anak mereka autis, sebagian orang tua merasa lega, ada juga yang merasakan perasaan keputusasaan, kesedihan dan bahkan kehancuran. Keberadaan anak autis dalam suatu keluarga membuat orangtua pasrah atau sebaliknya, orangtua menganggap anak autis sebagai suatu aib dalam keluarga. Orang tua yang memiliki anak autis, terutama ibu, lebih beresiko mengalami mengalami stres dan tekanan psikologis saat mengasuh (Boyd, 2002; Hayes \& Watson, 2012) . Stress yang dialami oleh ibu yang mempunyai anak autis lebih tinggi tiga kali lipat dibandingkan stres yang dialami oleh ayah. Stres tersebut karena kelelahan merawat anak, pekerjaan, dan lebih sedikit memiliki waktu untuk rekreasi.

Orang tua dengan anak autis juga meiliki tingkat perceraian yang lebih tinggi daripada orang tua yang memiliki anak normal [6].

\section{Metode}

Penelitian ini menggunakan desain fenomenologi. Partisipan dalam penelitian ini terdiri dari delapan orang ibu yang memiliki anak autis di Sekolah Luar Biasa (SLB) Binjai. Pemilihan partisipan dalam penelitian ini dengan menggunakan metode purposive sampling yaitu metode pemilihan partisipan dalam suatu penelitian dengan menentukan terlebih dahulu kriteria yang akan dimasukkan dalam penelitian [9].

Pengumpulan data dilakukan dengan in-depth interview. Proses analisa data dilakukan segera setelah selesai setiap satu proses wawancara, yaitu bersamaan dengan dibuatnya transkrip wawancara. Data yang diperoleh dianalisis dengan menggunakan metode Collaizi. Pengumpulan data dilakukan setelah mendapat izin dari Dekan Fakultas Keperawatan Universitas Sumatera Utara dan memperoleh ethical clearance dari Komisi Etik Penelitian Kesehatan Fakultas Keperawatan Universitas Sumatera Utara. Selanjutnya peneliti menjelaskan tujuan, manfaat dan prosedur pelaksanaan penelitian kepada calon partisipan dan bila partisipan bersedia berpartisipasi dalam penelitian ini maka partisipan diminta untuk menandatangi surat persetujuan sebagai partisipan (informed consent).

\section{Hasil}

Penelitian ini menemukan ada 5 tema terkait dengan pengalaman ibu yang memiliki anak autis di Sekolah Luar Biasa (SLB) Binjai, yaitu 1) mengalami masalah psikologis dan fisik, (2) menerima kondisi anak yang mengalami autis, (3) memberi perawatan pada anak, (4) mengalami kendala dalam merawat anak, dan (5) harapan ibu.

\subsection{Mengalami Masalah Psikologis dan Fisik}

Partisipan mengatakan bahwa mereka sangat sedih saat mengetahui bahwa anak mengalami autis. Hal ini sejalan dengan pernyataan partisipan yang mengatakan bahwa:

“....Nangis ajalah, nangis terus apalagi ini anak pertama, laki lagi...” (P1)

Partisipan mengatakan bahwa mereka merasat tidak percaya bahwa anak mengalami autis. Hal ini sejalan dengan pernyataan partisipan yang mengatakan bahwa:

“....Kadang mikir ya kok anak saya bisa kek gini yah gitu, apa salah saya gitu, kadang mikir kek gitulah...” (P1)

Partisipan mengatakan bahwa mereka merasa bingung dan tidak mengerti mengenai tentang autis. Hal ini sejalan dengan pernyataan partisipan yang mengatakan bahwa:

“....awal mula kan kita nggak tau kalau dia autis. Zaman- zaman dulu kan langka punya anak autis, saya kira karena terlambat ngomong ntah apa jadi setelah 3 tahun lah dokter bilang...” (P3)

Partsipan mengatakan bahwa saat merawat anak yang mengalami autis, mereka mengalami stres karena sulitnya mengatur anak. Hal ini sesuai dengan pernyataan partisipan berikut ini: 
“....ya dulu stres karna gimana ya, inikan dulu lasak kali, aktif la gitu, jadi ya stres dan capek ngurus dia....” (P2)

Partisipan mengatakan bahwa ibu yang memiliki anak autis khawatir akan masa depan anak. Hal ini sesuai dengan pernyataan partisipan berikut ini:

“....kek mana nanti kedepannya dia itu gimana gitu kalo dia ga bisa jaga diri dia sendiri...”(P6)

Partisipan mengatakan bahwa mereka merasa capek merawat anak mereka yang mengalami autis karena lasak. Hal ini sesuai dengan pernyataan partisipan berikut ini:

“....inikan dulu lasak kali, aktif la gitu, jadi ya stres dan capek ngurus dia....”(P2)

\subsection{Menerima Kondisi Anak Yang Mengalami Autis}

Partisipan mengatakan bahwa mereka telah menerima kondisi anak mereka yang mengalami autis dengan iklas, meskipun awalnya mereka mengalami penolakan saat pertama kali mengetahui bahwa anak mereka mengalami autis. Hal tersebut sesuai dengan pernyataan partisipan berikut ini:

“....ya kuncinya ikhlas aja ya emang ini udah dikasih sama Allah kaya gini gitu aja lah....”(P4)

Partisipan mengatakan bahwa mereka merasa bersyukur dengan kondisi anak, bahkan ada pula yang mengganggap bahwa anak mereka adalah suatu kebanggan di keluarga mereka. Hal tersebut sesuai dengan pernyataan partisipan berikut ini:

"....Ya disyukurin aja kadang ada yang lebih bawah dari kita yang lebih dari ini pun ada kan anak kita masih bisa berjalan, bisa makan bisa apa adakan yang tergeletak sama sekali ga ada perkembangannya itu kan ada juga..” (P6)

Partisipan mengatakan bahwa selama mereka merawat anak, mereka mendapatkan pembelajaran hidup yang dapat menjadikan mereka lebih bersabar. Hal tersebut sesuai dengan pernyataan partisipan berikut ini:

“...Lebih baiklah, maksudnya mungkin istilahnya orang bilang kita dapat anak seperti itu karena ada salah dulunya. Makanya sekarang harus menjadi lebih baik lah dan lebih sabar....” (P1)

\subsection{Memberi Perawatan Pada Anak}

Partisipan mengatakan bahwa saat mereka melihat perkembangan anak mereka yang terlambat seperti terlambat bicara, dan tidak bisa interaksi, partisipan membawa anaknya periksa ke dokter. Hal tersebut sesuai dengan pernyataan partisipan berikut ini:

“....ibu bawahlah ke dokter spesialis anak kan gitu trus ibu bilang sama dokternya itu anak saya kok ini ya dok blom pande cakap itu umur 2 tahun setengah waktu itu....”(P8)

Partisipan mengatakan bahwa mereka membawa anak mereka ke tempat terapi anak autis. Hal tersebut sesuai dengan pernyataan partisipan berikut ini:

“....Oiya langsunglah. Sudah tahu gitu kan saya langsung cari tempat terapi Simbolon apa lho gitu, lupa lho, di pelosok-pelosok. Baru satu tahun ini anak saya di sini, dulunya ikut terapi aja...” (P1)

Partisipan mengatakan bahwa mereka memberikan obat berupa vitamin dan obat penenang kepada anak mereka. Hal tersebut sesuai dengan pernyataan partisipan berikut ini: 
“....ada obat penenang. Dikasih setiap bulan....” (P2)

Partisipan mengatakan bahwa mereka melakukan pengontrolan diet terhadap anak mereka. Hal tersebut sesuai dengan pernyataan partisipan berikut ini:

“...Dulu kukasih diet dia, dia belum tau makanan, dia kan masi kecil, yang mana yang enak yang mana yang gak enak. Tepung roti gak masuk, coklat, kalo susu, susu kedelai. Kalo sekarang bebas....” (P1)

Partisipan mengatakan bahwa mereka selalu memantau anak saat beraktivitas, dan tidak pernah lepas dari pantauan. Hal tersebut sesuai dengan pernyataan partisipan berikut ini:

“....istilahnya kaya ngangon kambing gitu, kita, tengoi main gitulah diwaktunya apa keluar masuk2...” (P4)

Partisipan mengatakan bahwa mereka selalu membantu anak dalam melakukan berbagai kegiatan. Hal ini dikarenakan anak belum dapat secara mandiri melakukan kegiatan tersebut, misalnya makan mandi, berpakaian, dan lain-lain. Hal tersebut sesuai dengan pernyataan partisipan berikut ini:

“....Kalo dulu itu ya dia semua kita bantu, makan disuapin, mandi juga....” (P5)

\subsection{Mengalami Kendala Dalam Merawat Anak}

Partisipan mengatakan bahwa mereka kesulitan dalam mengatur anak karena lasak, dan suka berteriak-teriak. Hal tersebut sesuai dengan pernyataan partisipan berikut ini:

“....Kan dulu lasak lho, jadi kita dulu fokus ke dia aja. Punya anak nomor dua pun kita gak bisa jaga....” (P1)

Partisipan mengatakan bahwa mereka mengalami kesulitan ekonomi dalam memenuhi kebutuhaan anak seperti membawa terapi untuk anak autis. Hal tersebut sesuai dengan pernyataan partisipan berikut ini:

“....ya kami orang susah ga ada terapi2 lah....” (P7)

Partisipan mengatakan bahwa karena kesibukan merawat anak mereka berdampak pada aktivitas mereka di lingkungan, menjadikan mereka lebih sibuk, sehingga mereka tidak aktif lagi di lingkungan seperti pengajian di lingkungan. Hal tersebut sesuai dengan pernyataan partisipan berikut ini:

“....dulu yah sewaktu belom lahir ini, masih sering ikut, gitu. tapi sekarang yah terbatas lah kan kita pun jaga anak dirumah, nanti kalau dibawa dia lasak kan gak enak sama yang lain....” (P5)

\subsection{Harapan Ibu}

Hasil penelitian menunjukkan harapan ibu dengan anak yang menyandang autis adalah mampu berinteraksi seperti anak normal lainnya, sesuai dengan pernyataan partisipan:

“....Ya itu lah, pokoknya dia gak bisa kayak anak normalpun gak masalah, misaln ya ga bisa belajar kek anak normal bisa mengikuti seperti biasa, dia gak bisa ikuti gak papa,ada anak autis memang ada yang bisa ikuti, anak saya tidak sih nggak bisa. Cuma ya itulah penting bisa berteman dan bersosialisasi, gitu..." (P1)

Partisipan menginginkan agar anaknya lebih terarah dan pintar, ibu memiliki harapan untuk anaknya agar anak menjadi lebih terarah, sesuai dengan pernyataan partisipan :

“....ya semoga berubah dan berubah lagi. Pintarlah pintar dia....” (P3) 
Partisipan memiliki harapan anak mereka mandiri, agar mereka tidak bergantung lagi sama ibu mereka. Hal tersebut sesuai dengan pernyataan partisipan berikut ini:

“....ya pengen dia sembuh ya kan normal gitulah Cuma ga pun normal istilahnya dia bisa mandiri untuk dirinya sendiri, jangan jadi menyusahkan kakanya atau pun adenya itu aja bisa aja mandiri untuk dirinya sendiri itu ajalah..." (P8)

\section{Pembahasan}

Bagian ini akan diuraikan tentang pembahasan hasil penelitian dengan konsep atau teori yang ada, perbandingan dengan hasil penelitian yang pernah dilakukan sebelumnya berhubungan dengan pengalaman ibu yang memiliki anak autis di Sekolah Luar Biasa (SLB) Binjai.

Berbagai pendapat diungkapkan oleh partisipan, mulai dari perasaan selalu sedih, khawatir, perasaan menolak, perasaan tidak percaya akan kondisi yang dialami anaknya dan sempat tidak ingin menerima kenyataan setelah ternyata mengetahui anaknya menderita autis. Beberapa ibu juga merasa bingung dan tidak mengerti tentang autis sehingga mereka terus bertanya-tanya dan berusaha mencari tahu tentang autis. Sebagian orang tua, awal melihat kondisi anaknya, ibu merasa bingung dan tidak mengerti dengan kondisi anak, partisipan hanya berfikir mungkin ini hanya keterlambatan perkembangan pada anaknya. Hal ini sejalan dengan yang diungkapkan Safaria (2005) bahwa kebanyakan orang tua mengalami shock bercampur perasaan sedih, khawatir, cemas, takut, dan marah ketika mengetahui diagnosis bahwa anaknya mengalami gangguan autisme. Perasaan ini muncul karena anak merupakan masa depan keluarga, anak yang ditunggu-tunggu kehadirannya harus menderita suatu gangguan sebagaimana anakanak lainnya. Perasaan tidak percaya bahwa anaknya mengalami autisme kadang-kadang menyebabkan orangtua mencari dokter lain untuk menyangkal diagnosis dokter sebelumnya. Setelah mengetahui fakta dari berbagai sumber, kebanyakan orangtua dengan perasaan amat terpukul dan terpaksa menerima kenyataan bahwa anaknya adalah penyandang autisme.

Penelitian ini menunjukkan bahwa ibu yang memiliki anak autis mengalami masalah fisik seperti rasa capek saat merawat anak. Hal ini sejalan dengan Sebuah riset di Swedia tentang efek-efek kesehatan bagi orangtua yang memiliki putra-putri ASD menemukan dampak kesehatan yang signifikan bagi ibu, khususnya jika anaknya hiperaktif atau memiliki masalah perilaku [1]. Tim riset lain menanyai 299 orangtua untuk mengkaji kehidupan mereka secara detail. Dibandingkan dengan orangtua lain, orangtua dari anak autis terlibat di aktivitas fisik lebih buruk, selain juga kesehatan psikologis dan hubungan sosial lebih buruk dengan seluruh kualitas hidup lebih rendah.

Proses penerimaan orang tua yang memiliki anak yang mengalami autis diawali dengan proses penolakan yang ditunjukkan partisipan berupa kebingungan atas apa yang telah menimpa anaknya dan bingung akan apa yang harus dilakukan, selain itu orang tua merasa sedih akan kondisi yang dialami anak, dan tidak mempercayai kenyataan mengenai kondisi anak yang mengalami autis. Kemudian sampai pada proses yang terakhir yaitu penerimaan, dimana orang tua dapat ikhlas menerima kondisi yang dialami dengan tidak menjadikan anak sebagai beban dalam keluarga, merasa bersyukur anak masih lebih baik dari teman-temannya, dan menjadikan hal ini jadi pembelajaran hidup yaitu orang tua jadi lebih sabar. Hal ini sejalan dengan yang diungkapkan Yusuf (2002) mengungkapkan, penerimaan keluarga adalah salah satu tingkat kemampuan dan keinginan keluarga untuk hidup dengan segala karakteristik yang ada didalamnya. Menerima keluarga diartikan sebagai keluarga yang tidak bermasalah, tidak memiliki beban perasaan terhadap keluarga sehingga keluarga lebih banyak memiliki kesempatan untuk beradaptasi dengan lingkungan. Kemampuan penerimaan keluarga meliputi kemampuan untuk menerima orang lain sekurang kurangnya sabar menghadapi, bersikap tenang, dan ramah tamah.

Merawat anak yang mengalami autis, partisipan melakukan berbagai cara yaitu dengan membawa anak ke pelayanan kesehatan untuk periksa kedokter dan untuk terapi. Ibu membawa anaknya periksa ke dokter untuk mengetahui kondisi anak. Setelah mengetahui diagnosa anak yang mengalami autis, beberapa partisipan langsung membawa anak untuk terapi. Selain membawa ke pelayanan kesehatan, ibu juga melakukan perawatan dirumah seperti memberikan obat atau vitamin pada anak yang telah diresepkan oleh dokter. Hal ini sejalan dengan pernyataan Danuatmaja (2003) bahwa pemberian obat pada anak autis harus didasarkan pada diagnosis yang tepat, pemakaian obat yang tepat, pemantauan ketat terhadap efek samping obat dan mengenali cara kerja obat. perlu 
diingat bahwa setiap anak memiliki ketahanan yang berbeda-beda terhadap efek obat, dosis obat dan efek samping. Oleh karena itu perlu ada kehatihatian dari orang tua dalam pemberian obat yang umumnya berlangsung jangka panjang.

Ibu mengatakan bahwa selain memberi obat juga melakukan pengontrolan diet kepada anak. Hasil penelitian menunjukkan bahwa anak autis juga perlu memperhatikan pemenuhan makanan. Semua partisipan mengakui bahwa banyak sekali jenis makan yang perlu dihindari oleh anak mereka, seperti susu sapi, terigu, mentega dan makanan yang banyak mengandung pengawet. Upaya pengontrolan diet ini sangat berpengaruh pada perilaku anak. Salah satu partisipan mengatakan apabila anaknya menghidari makanan tersebut maka anaknya akan memperlilhatkan perilaku yang pasif. Hal ini sejalan dengan pernyataan Sastry \& Agirre (2012), bahwa terapi makanan (diet therapy) diberikan untuk anak autis karena masalah alergi makanan tertentu sering terjadi pada anak autis, seperti gangguan pencernaan, alergi, daya tahan tubuh yang rentan, dan keracunan logam berat. Gangguan-gangguan pada fungsi tubuh ini yang kemudian akan mempengaruhi fungsi otak. Diet yang sering dilakukan pada anak autis adalah GFCF (Glutein Free Casein Free). Pada anak autis disarankan untuk tidak mengkonsumsi produk makanan yang berbahan dasar gluten dan kasein (gluten adalah campuran protein yang terkandung pada gandum, sedangkan kasein adalah protein susu). Jenis bahan tersebut mengandung protein tinggi dan tidak dapat dicerna oleh usus menjadi asam amino tunggal sehingga pemecahan protein menjadi tidak sempurna dan berakibat menjadi neurotoksin (racun bagi otak). Hal ini menyebabkan terjadinya penurunan sejumlah fungsi otak yang berdampak pada menurunnya tingkat kecerdasan.

Beberapa partisipan bahkan mengawasi anaknya ketika bermain, karena anak autis mempunyai perilaku hiperaktif yang dapat membahayakan orang lain maupun dirinya sendiri, semua ibu bahkan sampai menunggu anaknya di sekolah mulai dari pagi hingga anaknya pulang sekolah. Hal ini sejalan dengan pernyataan Ball dan Bindler (2003) yang menyatakan upaya memonitor anak autis sepanjang waktu adalah tindakan perawat didalam mempertahankan lingkugan yang aman. Pengawasan ketat diperlukan untuk menjamin apakah anak mempunyai barang-barang yang membahayakan dirinya atau melibatkan perilaku yang berbahaya.

Hasil penelitian menunjukkan dalam memberikan diet pada anak beberapa ibu terkadang tidak didukung penuh oleh keluarga mereka terkadang diet anak menjadi tidak terkontrol karena selalu menuruti keinginan anak untuk jajan sembarangan, selalu membelikan makanan ringan yang banyak mengandung vetsin. Ini menjadi salah satu kendala dari beberapa partisipan dalam melakukan diet pada anak, dalam hal ini ibu kurang mendapat dukungan dari keluarga dalam merawat anak. Hal ini tidak sejalan dengan pernyataan Noor et al (2014) dalam penelitiannya yang mengatakan dukungan terhadap ibu selama merawat anak autisme dapat dilihat bahwa sebagian besar didapatkan dari keluarga inti yaitu suami (pasangan hidup) dan keluarga besar.

Masalah lain yang juga dihadapi oleh ibu karena anak yang keras kepala dan susah diatur, dan anak juga susah untuk tidur, ini membuat ibu menjadi lelah dalam mengahadapi anaknya. Hal ini sejalan dengan penelitian yang dilakukan oleh Marlinda (2011), dimana masalah kesehatan yang sering dialami anak autisme adalah gangguan tidur, gangguan saluran cerna, dan gangguan psikiatri. Gangguan tidur dialami oleh $44-83 \% \%$ anak autisme dengan gejala sulit tidur, bangun lebih cepat, kurangnya rutinitas tidur, pola tidur bangun yang tidak teratur. Gangguan tidur ini akan berdampak pada peningkatan agresivitas anak autisme itu sendiri.

Partisipan mengatakan bahwa selain kesulitan mengatur anak, ibu juga mengalami kesulitan dalam hal keuangan, terutama untuk membiayai kebutuhan anak seperti terapi. Hal ini sejalan dengan pernyataan Sastry dan Agirre (2012) bahwa orangtua yang memiliki anak autis menghadapi lebih banyak persoalan daripada orangtua dengan anak berkebutuhan khusus lainnya saat ingin mendapatkan perawatan kesehatan, intervensi dan terapi sesuai yang dibutuhkan putra-putri mereka. Tantangan-tantangan ini dan beban-beban finansial, pekerjaan dan waktu yang terkait, jelas besar sekali untuk keluarga-keluarga dengan ASD, bahkan mesti dibandingkan dengan keluarga yang anak-anaknya memiliki kebutuhan kesehatan mendesak.

Pengalaman lain yang diungkapkan beberapa partisipan, yakni kemandirian anak masih kurang, beberapa anak masih bergantung dengan ibu mereka, baik dalam hal memakai baju, makan, mandi dan buang air. Hal ini sejalan dengan penelitian yang dilakukan oleh Mariyanti (2010) yaitu anak penyandang autisme yang tidak mengikuti program ADLs maka anak-anak ini tidak akan mempunyai perkembangan kemampuan diri untuk makan, berpakaian, toileting, kebersihan diri, aktivitas rumah dan komunitas akan menjadi individu yang sangat tergantung 
pada orang di sekitarnya dan sering pula menjadi individu yang mempunyai perilaku maladaptif sebagai akibat tidak adanya kemandirian yang berkembang pada dirinya.

Partisipan dalam penelitian ini mengungkapkan harapan mereka untuk anaknya, mereka ingin anaknya mampu berinteraksi seperti anak normal lain, menjadi lebih terarah dan pintar, serta mampu untuk mandiri. Harapan ibu terhadap anaknya sangatlah besar karena anak merupakan masa depan bagi keluarga, hal ini didukung oleh pernyataan Safaria (2005) yang mengungkapkan bahwa anak adalah harapan keluarga, setiap orangtua pasti menginginkan anaknya lahir dalam keadaan yang sehat, cerdas, dan normal seperti anak-anak lainnya. Orangtua mengharapkan anaknya berhasil dalam pendidikannya, dan sukses dalam hidupnya.

\section{Kesimpulan}

Berdasarkan hasil wawancara mendalam yang dilakukan terhadap sepuluh partisipan, maka penelitian ini menemukan ada 5 tema terkait dengan pengalaman ibu yang memiliki anak autis di Sekolah Luar Biasa (SLB) Binjai yaitu, yaitu (1) mengalami masalah psikologis dan fisik, (2) menerima kondisi anak yang mengalami autis, (3) memberi perawatan pada anak, (4) mengalami kendala dalam merawat anak, dan (5) harapan ibu. Hasil penelitian ini diharapkan dapat memberikan landasan konsep bagi perkembangan ilmu keperawatan atau sumber informasi bagi mahasiswa terkait dengan asuhan keperawatan pada ibu yang memiliki anak autis. Hasil penelitian ini diharapkan dapat meningkatkan wawasan dan keterampilan guru di sekolah dalam memberikan dukungan bagi ibu yang memiliki anak autis sehingga orangtua mengerti tentang autis dan perawatannya. Hasil penelitian ini diharapkan dapat digunakan sebagai dasar untuk mengembangkan penelitian keperawatan bagi penelitian selanjutnya yang berkaitan dengan pengalaman ibu yang memiliki anak autis.

\section{Daftar Pustaka}

[1] Allik, H,. J.O. Larson, dan H. Smedje. (2006). Health-Related Quality of Life in Parents of School-Age Children with Asperger Syndrome or High-Functioning Autism. Health and Quality of Life Outcomes 4:1.

[2] Danuatmaja, Bonny. (2003). Terapi Anak Autis Di Rumah. Jakarta: PuspaSwara.

[3] Emam, AM., Esmat, Mamdouh., \& Sadek, AA. (2012). Candida Albicans Infection in Autism. Journal of American Science. 8(12): 739-744.

[4] Hallmayer, J., dkk. (2011). Genetic heritability and shared environmental factors among twin pairs with autism. Archives of general psychiatry. 68 (11), 1095-102.

[5] Hutton, AM., \& Caron, SL. (2005). Experiences of Families WithChildren With Autism in Rural New England. Focus On Autis and Other Developmental Disabilities. 20, 180-189.

[6] Howell, E., Littin, LS., \& Blacher, J. (2015). Family Impact of Children with Autism and Asperger Syndrome: A Case for Attention and Intervention. Austin Journal of Autism \& Related Disabilities. 1(2): 1008.

[7] Marlinda, E. (2011). Pengalaman Ibu Dalam Merawat Anak Dengan Kebutuhan Khusus : Auitis Di Banjarbaru Kalimantan Selatan. Tesis : Tidak dipublikasikan.

[8] Noor, Murniati, dkk. (2014). Pengalaman Ibu Dalam Merawat Anak Autis Usia Sekolah. Jurnal Autis, Hal 6-9

[9] Polit, D.F., \& Beck, C.T. (2012). Nursing Research: Generating and Assesing Evidence for Nursing Practice (9th ed). Philadelphia: Lippincott.

[10] Safaria, T. (2005). Autisme Pemahaman Baru untuk Hidup Bermakna bagi. Orangtua. Yogyakarta: Penerbit Graha Ilmu.

[11] Sastry, A,. \& Aguirre, B. (2012). Parenting Anak dengan Autisme. Yogyakarta: Pustaka Belajar. 